\title{
After the gold-rush
}

Wall Street's technology-led boom distorted the priorities of research agencies. Its bust should remind scientists that public trust requires careful attention to ethics.

T he investment bank Morgan Stanley is closing down its Competitive Edge Best Ideas mutual fund, reports The New York Times in one of those stolid and yet quietly humorous stories that have recently characterized the financial pages. Apparently the 'best ideas' of Morgan Stanley's analysts weren't coming to much, and the fund had lost half of its value in two years. That's enough bright ideas for the moment, investors seem to think.

Not all of the bright ideas touted on the world's stock markets towards the end of the 1990s were grounded in science or technology. Some, such as persuading people to buy dog food over the Internet instead of at a supermarket, were more like the product of a students' drinking party.

However, the boom was led by so-called technology stocks and was fuelled by sometimes unrealistic assumptions about the effect of science and technology on long-term economic growth. At the height of the boom, then US President Bill Clinton and other world leaders accredited science and technology with creating a 'new economy' that somehow justified the wanton overvaluation of stocks, especially technology stocks. Although most of these stocks were associated with information technology and telecommunications, the publication of the human genome and even the much-vaunted promise of nanotechnology were associated with economic well-being in general and some high-flying bubble stocks in particular.

That was then. Today, a more realistic set of investor expectations about the commercial potential of innovation are in the ascendant. This in turn is already reducing the number of commercial opportunities that are available to academic researchers, even in such hotbeds of technology transfer as San Francisco and Boston. For science as a whole, such realism is no bad thing, especially if it also leads to a correction of a short-sighted historical trend.

\section{Commercial interest}

During the economic boom of the 1990s, the connections between science and business deepened and widened. Despite a drumbeat of protest from 'traditional' academics - the very epithet reflects their marginalization - this trend was getting out of hand. Commercial interests were not just present on many university campuses, but paramount. The problem was less pronounced at such places as Harvard and Berkeley, which could afford to name their terms and their price, than at some of the middle-ranking universities that aspired to compete with them. This happened not only across the United States but around the world.

The price that the research universities paid was one of balance, as resources flooded into disciplines of commercial interest. Researchers in cell biology and information technology built palaces of gold, while purveyors of other branches of knowledge whole-organism biology and archaeology, for example, and even mathematics - have been shunted to the periphery, at least in the eyes of university administrators.

The same pattern has manifested itself in the funding priorities of research agencies, in the United States and elsewhere. Although it is in the long-term interest of any nation to develop a well-balanced portfolio of investment in curiosity-driven science - of the sort articulated most famously by Vannevar Bush for the US National Science Foundation at the end of the Second World War - few have done so, especially of late. Put simply, no one has been at the table to stand up for anthropology or geology, say, as politicians have looked to science primarily as an instrument to fuel growth in a few fashionable industries. During the past decade, in nation after nation, large grants and new projects have been focused on biotechnology, information technology and, more recently and to a lesser extent, nanotechnology.

Like Wall Street, the political leadership of research agencies has been overly fixated by these mantras. And like Wall Street, it should now rediscover the importance of what the money men call 'fundamentals'. The fundamental goal of science policy should be a well-balanced system of universities and government laboratories that explore the frontiers of knowledge. Surveys of public opinion in the United States show solid public support for investment in basic research that does not promise short-term economic benefits.

\section{A matter of trust}

The technology boom and bust may have distorted scientific priorities but it has not done much damage to the integrity of universities or to scientific institutions. At a time when scandals are shredding so many reputations — with businesspeople and accountants joining politicians and journalists as targets of public opprobrium in the United States — trust in science remains deservedly high.

The scandals that have shaken financial markets have touched on science, however. For instance, ImClone Systems, one of the companies where allegations of insider dealing have shaken investor confidence, is a biotechnology company with friends in high places in US biomedical research. But so far science as a whole has escaped damage. Nevertheless, dangers lurk as remaining scandals unfold: the situation at Lucent Technologies, for example, continues to warrant careful attention (see Nature 418, 5; 2002). And complacency about scientific misconduct still pervades the community to a surprising degree (see pages 113 and 120).

The possible cost of such complacency is, perhaps, the most important message that scientists can draw from this year's financial scandals. It is tempting but misguided for scientific leaders to believe that, because a false result will be corrected in time by its failure to be replicated, research misconduct doesn't really matter. Business leaders had a similar credo: they said that markets would correct for dishonest business practices, in the fullness of time.

This isn't good enough. Perhaps a better working assumption should be that people will get away with what they can get away with. Since the obdurate Congressman John Dingell (Democrat, Michigan) was deposed as chair of the Commerce Committee of the US House of Representatives in 1994, political scrutiny of the scientific community over misconduct has relaxed. Most researchers are honest and not wealthy, and are not surprised to learn that corporate America is full of rogues. Before drawing too much comfort from their come-uppance, however, it would make sense to ensure that research has its own house in order. 